Bangladesh J. Plant Taxon. 28(2): 379-384, 2021 (December)

(C) 2021 Bangladesh Association of Plant Taxonomists

DOI: https://doi.org/10.3329/bjpt.v28i2.57133

\title{
HUMARIA LAEVISPORA, A NEW CRYPTIC SPECIES OF PEZIZALES (PYRONEMATACEAE, ASCOMYCETES) BASED ON MORPHOANATOMICAL AND PHYLOGENETIC ANALYSIS FROM PAKISTAN
}

\author{
Abdul Rehman Niazi*, Ayesha Faroodi and Najam-Ul-Sehar Afshan \\ Institute of Botany, University of the Punjab, Lahore, Pakistan
}

Keywords: Humaria; Pezizales; Himalayan moist temperate forest; Pakistan; nrITS; Phylogeny.

\begin{abstract}
In order to explore the biodiversity of mushrooms from Pakistan, authors come across a new Humaria sp. associated with Pinus wallichiana from Pakistan's part of Himalayan moist temperate forests. Morpho-anatomical and phylogenetic characterization were used to elucidate their taxonomic affinities. Morphological and phylogenetic analysis confirms that it is a new species of Humaria. Humaria laevispora is subsequently described in detail and compared to closely related taxa Humaria hemisphaerica. The analysis also reveals that epigeous Humaria sp. is sister to hypogeous Genea spp. reflecting epigeous habit in Humaria a derived condition.
\end{abstract}

\section{Introduction}

Peziza species having hairs and setae on apothecial margins and receptical surface were termed as "Lachnea" by Fries (1823). The presence or absence of these hairs served as a base for identification under Lachnea, while other important characters, like surface morphology, hair origin, shape, color in the ectal excipulum, shape of apothecia, hymenialcolor, ascospore surface morphology and guttulation were ignored by the earlier workers. After 1960's Significant changes have been made in the classification system of the operculate cup-fungi (Eckblad, 1968; Rifai, 1968; Dennis, 1978; Eriksson and Hawksworth, 1998).

Peziza hemisphaerica Fr. was considered among the Lachneae. Later, Fuckel (1870) transferred P. hemisphaerica to Humaria. Boudier (1885) raised Fries's genus Peziza to the family level, under which he accepted five tribes, including Lachneae (as "Lachnés"). Since Boudier (1885) used outer morphology to distinguish suborders, he separated cup fungi into Cupules, Lenticles, and Mitres. By this taxonomic sceme, Humaria hemisphaerica (Wiggers ex Fr.) Fuckel, producing cupulate apothecia, was accepted in the tribe Lachnes of the family Pezizés (under Cupules).

Sixteen species of Humaria Fuckel have been reported from north temperate regions all over the world. From Pakistan, three Humaria species have been reported based on morphology viz., $H$. gregaria, H. hemispaerica and H. woolhopeia (Ahmad et al., 1997), while no species on the phylogenetic basis has been documented from Pakistan so far. This is the first time from Pakistan that one new species of Humaria is described based on the molecular and phylogenetic basis. This new species of Humaria was collected during monsoon season of 2015 from Khanspur, Ayubia (KP) of Pakistan which lies in moist temperate west Himalayan mountainous range.

*Corresponding author, E-mail: drarniazi.botany@pu.edu.pk 


\section{Materials and Methods}

Sampling and morpho-anatomical characterization

Sampling was carried out during the summer rainy season from Khanspur, Ayubia (KP). Apothecia were carefully removed from substrate and collected in paper boxes with proper tagging. Field notes were prepared of fresh specimens and colors were designated following color charts of Munsell (1975). Specimens were dried using fan heater and stored in polythene bags. For further proceedings ascomata were brought back to laboratory. Free hand sections of dried specimens were made, placed in rectified spirit for 10 minutes and then rehydrated in water. The sections were mounted in 5\% $\mathrm{KOH} \&$ Melzer's reagent to see color reactions. Anatomical features were observed using compound microscope and photographed using microscope camera HDCEX5 5.0MP. Measurements were recorded in 5\% KOH using Carl Zeiss Jena ocular micrometer. The dimensions of Ascospores are given in the form of (a) b-c (d) $\times(e) f-g(h),[a v X$, avQ] where $\mathrm{b}-\mathrm{c}$ and $\mathrm{f}-\mathrm{g}$ include the spore length and width respectively between the 5 th percentile and the 95th percentile, (a) and (d) the shortest and the largest spores recorded, (e) and (h) the narrowest and the broadest spores recorded, avX the mean of length by width \pm SD (standard deviation), avQ the mean of $\mathrm{Q}$ coefficient (length/width ratio). Measurements of other microscopic structures (Asci, paraphysis) include the range between the extreme values measured in length and width. Line drawings were made using Leitz wetzlar camera lucida. Voucher specimens were deposited in the LAH (Herbarium, Department of Botany, University of the Punjab, Lahore, Pakistan).

\section{DNA extraction/ amplification/sequencing}

Two different protocols have been employed to extract genomic DNA from dried ascomata. Modified CTAB method Brunz (1995) and Proteinase K method (100 $\mu$ l lysis buffer and $2.5 \mu \mathrm{l}$ proteinase $\mathrm{K})$ using ammonium sulphate lysis buffer $\left(0.8 \mathrm{M}\right.$ Tris- $\mathrm{Hcl}, 0.2 \mathrm{M}\left(\mathrm{NH}_{4}\right)_{2} \mathrm{SO}_{4}, 0.2 \% \mathrm{~W} / \mathrm{V}$ Tween-2; Soils BioDyne, Tartu, Estonia). Internal transcribed spacer (ITS) region of nuclear ribosomal DNA including 5.8s was amplified using two sets of primers. One set, ITS1F/ITS4 was used for DNA extracted from modified CTAB method. Second set of primers ITSOF (ACTTGGTCATTTAGAGGAAGT) and ITS4-Pyr (TTTGCCRCTTCACTCGCA) (BengtssonPalme et al., 2013) was used for DNA extracted from Proteinase K method. ITS5 (GGAAGTAAAAGTCGTAACAAGG) primer was used for sequencing. Both strands of the PCR products were sequenced at BGI-Hongkong (China), TsingKe (China) or Genewiz (UK). The parts of Isotype are vouchered in TU under accession TU116929. The sequence is deposited in UNITE under accession UDB02504.

Sequences of ITS region of 5.8s nrDNA were BLAST searched. Unidentified and ambiguous sequences have been omitted from the analysis. Sequences of closely related taxa retrieved from GenBank and published data were aligned in MUSCLE and phylogenetic tree was constructed with MEGA6 using Jukes-Cantor model at 1000 bootstraps. The evolutionary history was inferred by using the Maximum Likelihood method (Stamatakis, 2006).

\section{Results and Discussion}

Phylogenetic analysis

Initial blast showed 97\% identity with Pezizales sp. (HG797009) and 96\% with Fungal sp. (HG796896) from Pakistan with 93\% and 94\% query cover and $0.0 \mathrm{E}$ value repectively. The analysis involved a final data set of 19 nucleotide sequences. The Aligned sequences showed a total of 999 positions, of these 325 characters are conserved, 657 variables, 514 parsim-info and 142 singletons. (Fig. 1). It formed two major clades (Clade I \& III) and a smaller (Clade II) of Wilcoxina rehmii. Helvella crispa has been selected as out group. AF73 clustered with sub-clade 
of Humaria hemisphaerica containing 3 sequences that formed sister clade with Genea verucosa, G. harknessi, G. gardnerii.

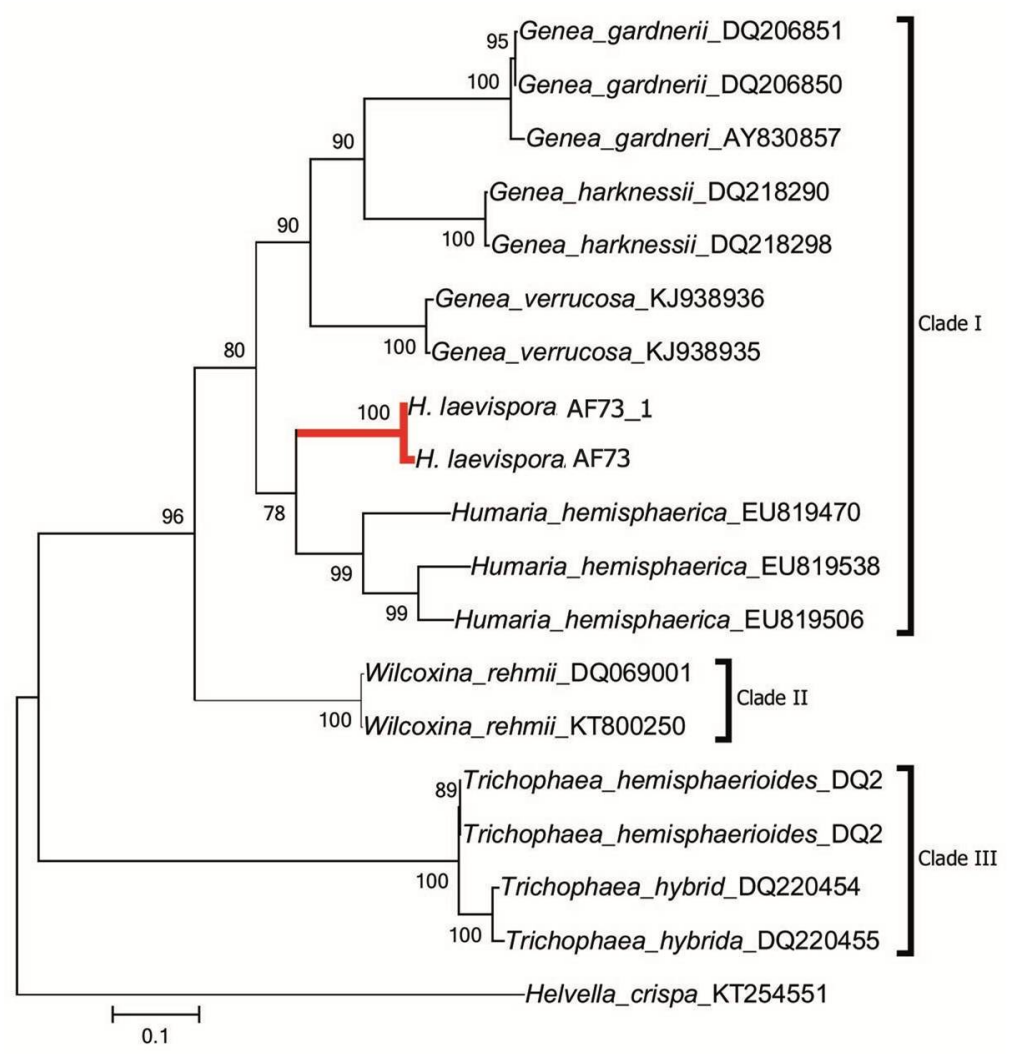

Fig. 1. Molecular Phylogenetic analysis by Maximum Likelihood method. Drawn from dataset of 18 ITS sequences belonging to 17 sister species of genus Humaria and Helvella crispa used as outgroup species. The new species is highlighted in bold.

\section{Humaria laevispora Niazi \& Farooqi, A sp.nov. UNITE accession no. UDB02504}

Diagnosis: this species is distinguished from other species by yellow brown to dark brown excipular hairs and their smooth walled spores.

Etymology: refers to the smooth ellipsoidal ascospores having large central guttule on maturity.

Fig. 2 (A-G)

Apothecia: Epigeous, inconspicuous, small $0.7-1.7 \mathrm{~cm}$, scattered to gregarious, sessile, fleshy, at first cupulate, opening up to somewhat discoid at maturity, interior greyish white, white when over ripe apothecia, exterior brown, hymenium smooth, outer surface hairy, dense mat of brown hairs, margins fringed with light brown hairs, more towards periphery, centrally attached, stipe absent. 

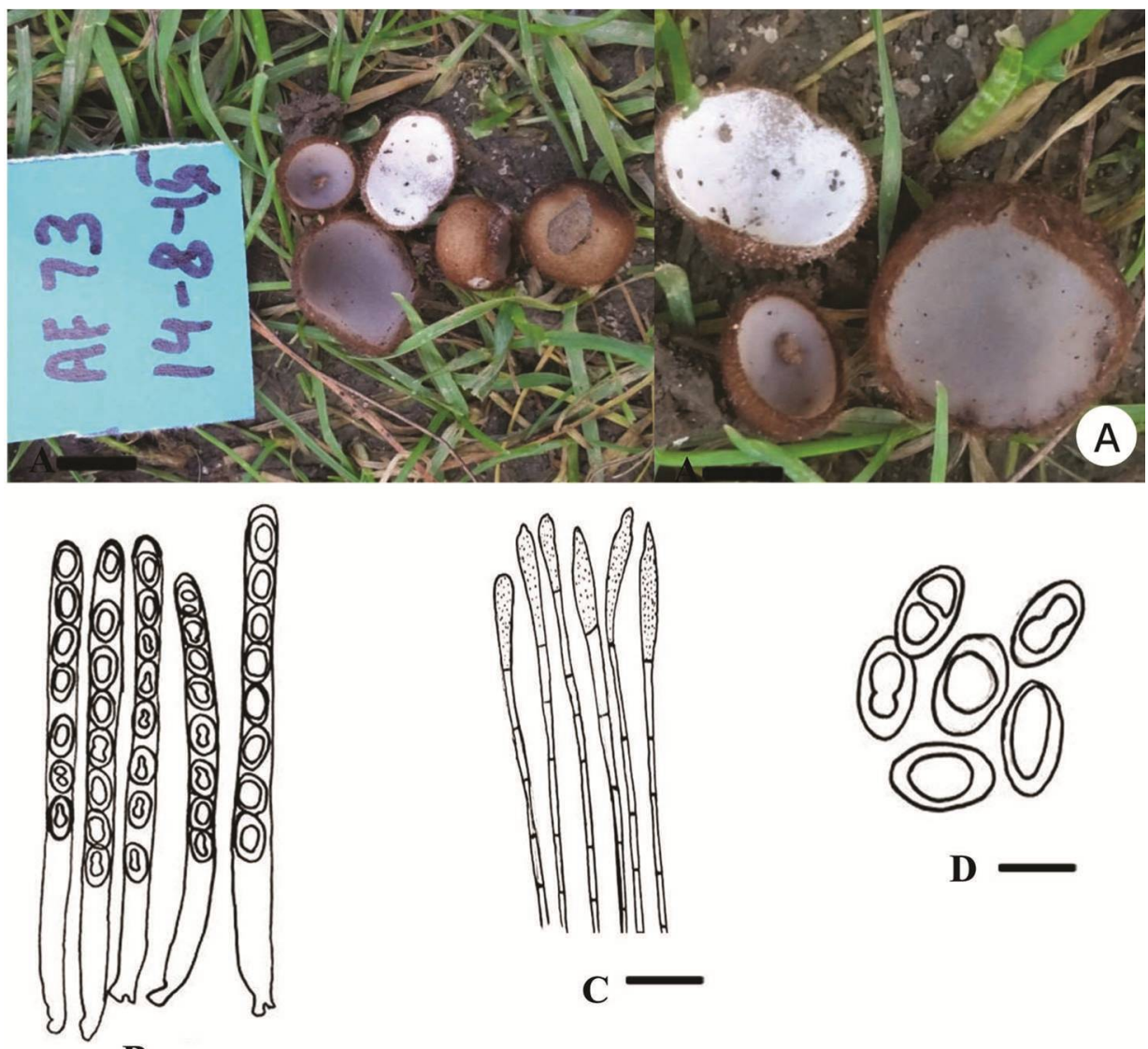

D
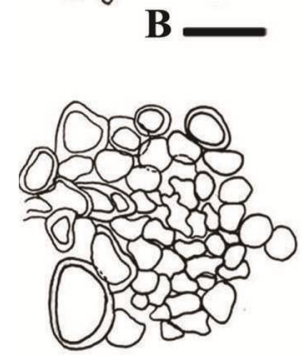

$\mathbf{E}$
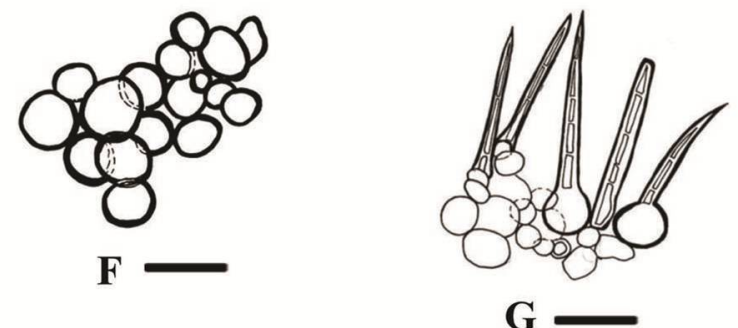

Fig. 2 A-G: Humaria laevispora. A. Ascocarps B.Asci containing ascospores C. Paraphyses D. Smooth elliptical spores E. Part of excipulum F. Basal cells of excipular hairs G. Excipular hairs of margins with variable bases. Bars A: 10mm, B-G: $10 \mu \mathrm{m}$

Hairs: Excipular hairs at periphery are different from those on outer surface. Marginal hairs stiff, pointed, pale yellow brown when immature, maturing to dark brown, thick walled, multiseptate, 3-7 septa, tips sword-blade like, apices are usually sharp pointed, acute but many hairs with obtuse apices, variable near base, mostly with small basal swellings, some with bulbous bases, septum separates the bulbous base from elongated part of hair, originating from 
specialized globose cells, basal cells brown, thick walled, 164-340 (16) $\mu \mathrm{m}$ long, 11-19 (16) $\mu \mathrm{m}$ broad, 3-5 $\mu \mathrm{m}$ wall thickness, not deeply rooted. Asci: Cylindrical, operculate, eccentric operculum, unitunicate, uniseriate in the ascus, non-amyloid, 8 spored, 238-315 $\times 14-21 \mu \mathrm{m}$, some forked at the base. Ascospores: Smooth, broadly ellipsoidal, uninucleate, immature spores having two oil droplets, mature spores uniguttulate. (20-)22 -27(-28) $\times(13-) 1417(-18) \mu \mathrm{m}$, avl $\times \mathrm{avw}=$ 24-15 $\mu \mathrm{m}$, avQ $=1.6 \mu \mathrm{m}$. Paraphyses: Slender, filiform, septate, clavate, longer than asci, hyaline, paraphyses tips variable, mostly broadened at the apices having prominent cellular contents, some knob shaped, paraphyses tips 6-10 $\mu \mathrm{m}$ broad.

Excipulum: Hyaline to brown, excipular cells that give rise to marginal hairs are globose, dark brown, thick walled, $28-55 \mu \mathrm{m}$ in diameter, 2-3 cells thick, immediately below are hyaline cells, 161- $444 \mu \mathrm{m}$ thick, ectalexcipulum of textura globosa, medullary excipulum of textura angularisglobosa, hyaline,2-3 cells thick.

Holotype: PAKISTAN. Khyber Pakhtunkhwa, Khanspur village, Ayubia, Himalayan moist temperate forests, on moist soil penetrated by gymnosperm roots amongst mosses, gregarious, 2575m a.s.1 14 August 2015, A. R. Niazi, Ayesha Farooqi, AF73(LAH14815), UNITE Accession No: UDB02504

Phylogram was constructed using closely related sequences retrieved from GenBank and published data (Perry et al., 2007). As Pfister (1984) already pointed out that $H$. hemispaerica is highly supported epigeous sister group to hypogeous Genea, Genabea and Gilkeya. The epigeous habit of this taxon may be a secondarily derived condition (Perry et al., 2007). Kimbrough (1994) found that ascospore ontogeny of G. gardnerii was very similar to that observed in $H$. hemisphaerica. Pfister (1984) also noted that some of the tomentose members of Genea appeared anatomically more similar to Humaria than to Jafneadelphus. Sequences of H. hemisphaerica included in the phylogenetic tree have American origin associated with Quercus alba while Pakistani AF73 (LAH14815) was found to be associated with Pinus wallichiana. Trichophaea share similar spore ontogeny with Mycolachnea as indicated by Wu and Kimbrough 1992. Both the sequences of AF73 are separated with 78\% bootstrap value from H. hemisphaerica which support our morpho-anatomical findings. AF73 is characterized by sessile, cupulate apothecia having exterior brown surface and greyish white interior, pale yellow brown to dark brown excipular hairs, smooth ellipsoidal ascospores having large central guttule on maturity. Spore guttulation exhibit fusion like phenomenon, immature spores are characterized by two small guttules which later on fuse and form one large central guttule. Excipular hairs are neither swollen nor strictly bulbous near base. Similarly, paraphyses tips also show great deal of variation from clavate to knob like apices. $H$. hemisphaerica on the other hand has elliptic ascospores with coarse warts having two oil droplets. These characters, especially smooth spore wall make it distinct from $H$. hemisphaerica which is supported from phylogenetic analysis as well suggesting it to be different, altogether new species.

\section{Acknowledgments}

Authors are very grateful to Dr. Lehoo Tedersoo, who helped in the molecular phylogeny of the specimen and improvement of the manuscript and Prof. Dr. Abdul Nasir Khalid for providing lab facilities.

\section{Conflict of Interest:}

Authors have no conflict of interest to disclose 


\section{References}

Ahmad, S., Iqbal, S.H. and Khalid, A.N., 1997. Fungi of Pakistan. Sultan Ahmad Mycological Society, Pakistan. 50 pp.

Bengtsson-Palme, J., Ryberg, M., Hartmann, M., Branco, S., Wang, Z. and Godhe, A. 2013. Improved software detection and extraction of ITS1 and ITS2 from ribosomal ITS sequences of fungi and other eukaryotes for analysis of environmental sequencing data. Methods Ecol Evol. 4: 914-919.

Boudier, J.L.E. 1885. Nouvelle classification naturelle des Discomycetès charnusconnusgènèralement sous le nom de Pezizes. Bulletin de la Société Mycologique de France 1: 91-120.

Brunz, T.D., 1995. Thoughts on the processes that maintain local species diversity of ectomycorrhizal fungi. 63-73, In; HP Collins et al. (eds). The significance and regulation of soil biodiversity. Springer Netherlands.

Dennis, R.W.G. 1978. British Discomycetes. J. Cramer, Valduz. 585 pp.

Eckblad, F.E., 1968. The genera of operculate Discomycetes: a re- evaluation of their taxonomy, phylogeny, and nomenclature. Nytt Magasin for Botanikk 15: 1-191.

Eriksson, O.E. and Hawksworth, D.L. 1998. Outline of the Ascomycetes: Systema Ascomycetum 16: 83-301.

Fries, E.M., 1823. Systema mycologicum. Vol. 2. Ex Officina Berlingiana, Lundae, Sweden. 620 pp.

Fuckel, L. 1870. Symbolaemycologicae. BeiträgezurKenntnis der rheinischenPilze. Jahrbücher des Nassauischen Vereins für Naturkunde, pp. 1-459.

Kimbrough, J.W. 1994. Septal Ultrastructure and Ascomycete Systematics. In: Hawksworth DL (ed), Ascomycete Systematics: Problems and Perspectives in the Nineties. Plenum Press, New York. pp. 127141.

Munsell, A.H. 1975. Munsell soil color charts. Macbeth Division of Kollmorgen Corporation. Baltimore, Maryland.

Perry, B.A., Hansen, K. and Pfister, D.H. 2007. A phylogenetic overview of the family Pyronemataceae (Ascomycota, Pezizales). Mycol. Res. 111(5): 549-571.

Pfister, D.H., 1984. Genea-Jafneadelphus d a Tuberalean-Pezizalean connection. Mycologia 76: 170-172.

Rifai, M.A. 1968. The australasian Pezizales in the herbarium of the Royal Botanic Gardens, Kew. Verh. K. ned. Akad. Wet., II, 57(3): 1-295.

Stamatakis, A. 2006. RAxML-VI-HPC: maximum likelihood-based phylogenetic analyses with thousands of taxa and mixed models. Bioinformatics 22: 2688-2690

Wu, C. G. and Kimbrough, J.W. 1992. Ultrastructural investigation of Humariaceae (Pezizales, Ascomycetes). I. Ascosporogenesis in Trichophaea (tribe Lachneae). Int. J. Plant Sci. 153 pp.

(Manuscript received on 5 June 2021; revised on 3 December 2021) 